\title{
The survival of small states in the Gulf region: COVID-19, pandemic politics and the future of niche diplomacy
}

\author{
Beverley Milton-Edwards ${ }^{1}$ i
}

(c) The Author(s), under exclusive licence to Springer Nature Limited 2021

\begin{abstract}
The Gulf is increasingly recognized as one of the most dynamic and unstable regions in the international system. Within the region, the survival of small states can no longer be taken for granted and power relations are conflictual. The hegemonic ambitions of larger regional state actors draw small states into a contested orbit and emphasize the fluidity of pre-existing notions of the balance of power. This has led to forms of fragmentation. Small states can no longer sit comfortably under the shelter of regional and even external super-powers. The impact of the COVID-19 pandemic on small states like Kuwait and Qatar is a useful prism to examine the ways in which such small states attempt to project power and sovereignty through their diplomatic responses. Our argument, here, is that such discourse is framed as part of an ideational and material construct for state resilience within a regional and international system that is perceived as predatory. Yet pandemic politics reveals both the opportunities and limits of such approaches.
\end{abstract}

Keywords Small states $\cdot$ COVID-19 $\cdot$ Resilience $\cdot$ Niche diplomacy

\section{Introduction}

Until the advent of the COVID-19 pandemic, the first 3 months of 2020 had presented Kuwaiti and Qatari foreign policy-makers with the usual but demanding challenges that face small countries that are not only located on a geostrategic fault line in the globe but surrounded by larger state actors (Iraq, Iran and Saudi Arabia). Historically, this has made both countries vulnerable to the power-struggles between such states as they seek to dominate the region. In early 2020, such power politics were evident in the ongoing effects of increased tensions centred on Iran.

Moreover, as a small state, Qatar alone was still contending with the effects of more than 36 months of a diplomatic embargo combined with a land, maritime and

Beverley Milton-Edwards

b.milton-edwards@qub.ac.uk

1 Queen's University Belfast, Belfast, UK

Published online: 30 September 2021 
aviation blockade imposed on it by Bahrain, Egypt, Saudi Arabia and the United Arab Emirates (UAE). The quartet of states had accused Qatar of embracing ties with terrorists and interference in their sovereign affairs (Wintour 2017). In many respects, the blockade had already tested Qatar's resilience as a small state, to avoid compromise on its own organizing narratives, and to achieve agency.

For Kuwait, the controversy surrounding the blockade on Qatar and the questions it raised about ambitions among GCC countries to disrupt or threaten their neighbour's sovereignty revived painful memories of the devastating assault on its own dominion following the August 1990 invasion of the country by Iraq. Narratives of resilience, authority and the almost constant demand for sovereignty vigilance thus exemplify indigenous dimensions of the foreign policy of such small states including their approaches to alliance building, security dilemmas and regime survival in one of the least peaceful regions of the globe.

Since the early 1990s, it is clear that both Kuwait and Qatar had to prioritise conceptual dimensions of foreign policy that reflected their own agency while in the shadow of larger regional powers such as Iraq, Iran and Saudi Arabia. In 1991, in the wake of the Iraqi invasion and occupation of their country, as well as accompanying plunder of their resources, Kuwait's ruling elite had experienced a painful lesson in vulnerability and dependence. One consequence of the American-led coalition to liberate Kuwait was the rise of domestic opposition groups in Saudi Arabia and other Gulf countries. Foreign policy began to reflect this duality of vulnerability and dependence as well as a rising sovereign assertion of Kuwaiti agency. For Kuwait, in particular, this was symbolized in its attachment to the coalition of the Gulf Cooperation Council (GCC). Kuwait and Qatar, along with other small states including the UAE and Oman, had attempted to cooperate to place constraints on the agenda of Saudi Arabia in its pursuit of domination of the Gulf regional order. Saudi Arabia's control was seen as part of the natural regional order because the state is the largest Sunni oil producing monarchy in the area.

The Arab uprisings of 2010 and 2011 created a series of threats and opportunities for ruling elites of Gulf countries. Contrary to expectation "smallness" was no impediment to a newly emergent trend of active foreign policy across the Middle East and North Africa region. This high level of activity from Gulf states was disruptive to dimensions of regional order that were already in significant upheaval or threat. Active foreign policy by a number of small states, including Qatar, was multi-dimensional and evident in diplomacy, peace-making, humanitarian efforts, support and advocacy for mobilized populations, armed actors, and defensive power holders as well as new power contenders. In some spheres of the Middle East and North Africa, small Gulf countries were standing shoulder to shoulder but in others they were on opposite sides of political divides. This new political environment also established greater agency and autonomy from the traditional consensus of regional leadership determined by Saudi Arabia. For its part, Saudi Arabia actively sought to preserve itself from any threat perceived as inherent within the populist risings and emergent political forces, including the sectarian ambitions of Iran in Arab states, as well as the Muslim Brotherhood, in the region.

The ambitions of small Gulf states, however, have not only been perceived as at odds with those of Saudi Arabia, but in Qatar's case brought it into direct 
confrontation with the regimes in Riyadh and Abu Dhabi. More specifically, significant tension has centred on the opposition by Saudi Arabia and the UAE to Qatar (and Kuwait's) divergent policy approaches to the Muslim Brotherhood (Freer 2015).

In 2014 and again in June 2017, one major outcome for Qatar, as discussed above, was the boycott and eventual imposition of blockade against organized by Saudi Arabia and the UAE and supported by Bahrain and Egypt (Ulrichsen 2020a). In the ensuing three and a half years, before the Blockade ended with the Al Ula Agreement in January 2021, the ongoing enmity framed by the blockading countries against Qatar also brought to the surface issues about balances of power for small states in the Gulf region. It also highlights the constraints of smallness, the vulnerabilities of sheltering, and the abilities of small states to survive through generating niche diplomacy activities while maintaining sustaining strategies for survival.

Such realities were fully exposed by the outbreak of the COVID-19 pandemic in the Gulf region. The truism that the COVID-19 virus recognized no borders, religions or ethnicities has been evident in its designation as a global pandemic and the threat it has posed to the stability, prosperity and effectiveness of governance in the region and beyond. The countries of the Gulf have thus not only contended with domestic challenges but part of responsiveness is clearly found in foreign policy activities. We thus commence this paper by analysing the literature on small states and niche diplomacy to assess the evolution of the concept in international relations literature. By examining Kuwait's and Qatar's approaches to foreign policy in the initial stages of the COVID-19 crisis, which we coin "mask diplomacy", we are afforded an opportunity to highlight the theoretical parameters and boundaries at work. We argue that, despite similar approaches to convert forms of small state power, the limits of niche diplomacy was reached in how both countries set or tailored their foreign policy agendas in this period.

\section{Lilliput states}

International relations literature has long engaged-and understandably so-with statehood and sovereignty. Theoretical frames have traditionally focused on the state and developing discourse reflected in realist narratives on power within the international system. Within such conceptions, state power was determined by size with inherent assumptions reinforced throughout the Cold War that big states would dominate world order and small states would remain much more subject and lacking in agency. This highlights what Steinmetz and Wivel call 'the focus from the power that states possess to the power that they exercise' (p. 7). Given the inherent symbiosis between power and size differentials at work, the notion that small states somehow constituted forms of diminished sovereignty entered normative discourse. Fox reinforces this by contending that within the international system small states can never leverage power in the way that larger states can. Nor, Fox argues, can they engage in effective opposition to the implementation of power wielded against them by such big states (Fox 1959). 
This narrative highlights power in forms of an international system shaped by dominant-subordinate state-to-state relationships privileging big or strong states over small or weak states (Waltz 1986). Furthermore, as Waltz argues, this lends credence to a structuralist discourse on statehood where, within the international system, 'states are differently placed by their power' and their power status is dependent on size $(1991,31)$. Differentials of power diminish, in such discourse, as small states are cast as almost perpetually seeking to attain forms of status akin to big or strong states (Hey 2003). This dichotomy had implications for the interconnected realms of national interest, security and foreign policy making for small states. Much academic literature has portrayed their vulnerability as fundamental to the ways in which they forged external relationships especially with respect to security sheltering behaviours (Antola 2002). In the wake of the Cold War, and uncertainty about the transitions within the world order international relations literature re-visited the concept of small states.

The issue of the proliferation of small states in most literature, especially in relation to structure-agency opposition, tended to reinforce Eurocentric biases and dominance of associated governance norms. This approach reinforced the notion that small states tended to exhibit weakness and were harbingers of fragility, collapse and engage in conflict with other states. In many respects, there is evidence of cognitive dissonance in relation to a new world order where in fact the majority of states could be classified as small and in many respects have become increasingly powerful. As a conglomeration, they also presented challenges to alliance formation and international norms of cooperation like never before (Bailes et al 2016).

Within the realms of foreign policy, small states were ascribed roles between neutrality, balancing and bandwagoning (Walt 1987, p. 17). None of these roles was perceived as implicitly powerful but rather reflect a dissipation or weakness of power in relation to large or strong state actors (Handel 1981). Such approaches have tended to seek to preserve particular realist frames of the international order where small state power dynamics are deemed insufficient in and of themselves to adjust system norms and behaviours. As such, the exogenous environment is deemed to be far more significant to small states and thus places additional burdens in terms of having foreign policy approaches that establish sufficient defensive capacity so as to ward off the threats posed by larger hegemonic seeking neighbours (Jesse and Dreyer 2016). Perceptions of small state characteristics are, it can be contended, part of the power projection dynamic of so-called larger or stronger states shaping the appreciation of the role and function of foreign policy (Vital 1971).

\section{Niche construction and agency}

In the contemporary era, discourse on the role of small states has accommodated to the reality of the enduring (albeit fragile) presence and persistence of small states in the international system. Some literatures reflected arguments that small states can be perceived as establishing forms of agency through activities such as norm entrepreneurship and niche diplomacy. We contend that small states are seen as increasingly resilient through necessary security sheltering bargains that in the 
case of resource rich states have a transactional character inverting some dimensions of dependency theory. However, this is not sufficient in and of itself to upend realist frames but it does bear important consideration in an era when large states are retreating from international leadership, consensus building and norm determination.

Both Kuwait and Qatar are discursively defined as small, micro or even citystates. Since independence, respectively, in 1961 and 1971, the monarchies of both states have determined foreign policy agendas that inherently recognize "small" geographical status in a context of much larger regional neighbours of Iraq, Iran and Saudi Arabia as well as superpower rivalry until the end of the Cold War. Nevertheless, the two countries could employ large and growing economic power (derived from hydro-carbon revenues to the state) to leverage particular dimensions of their foreign policy agenda and engage in forms of status and security seeking (Wohlforth et al 2018). Growing wealth coincided with the acceleration of globalization in which, according to Ulrichsen, the 'very notion of power and the channels through which it is transmitted' were malleable enough to allow countries like Kuwait and Qatar to play outsized roles in the international system $(2013,4)$.

Additionally both countries engaged in the construction and representation of soft power credentials particularly in relation to themes of development, humanitarianism, and conflict resolution, especially mediation (Nye 2004). This created opportunities to chase global status representing values considered to be part of the postCold War liberal international order. Such action through strategic agenda setting is perceived as a way for such countries to increase their 'international profile, ... to protect ... from the perils of small-state anonymity and vulnerability-perils of the kind from which Kuwait suffered in 1990' (Khatib 2013, 418).

One way in which Kuwait signalled its more global ambition was indicated in the 1970s when it began to emerge as a major donor of development aid and humanitarian assistance. In 1961, Kuwait had established a fund for Arab Development later coined the Kuwait Fund. By 2009 the fund had actually disbursed assistance to over 100 countries in and beyond the Arab world to include Asia and Africa (McKinnon 1997). In terms of aid giving, Leichtman (2017) goes as far as to describe Kuwait's role as dominant globally. Certainly, there are positive dimensions of this particular type of humanitarian leverage which some might argue accounts for Kuwait's upscaled role in international diplomatic forums such as UNSC since 2018.

This desire for autonomy in foreign policy is strongly reflected in the soft power attributes of both states evident in the niches that their diplomatic activities and allied resources seek to fill or alternately carve for themselves. In the example of Qatar, this has, according to Khatib, been achieved through political pragmatism, adaptation and the establishment of linkages that often transcend normative organizing categories of diplomatic relations (2013). Qatar, according to Fromm, exemplifies positioning by such small states to become indispensable "bridging" agents regionally and globally which larger states have a concern to protect (2017). Conceiving and enacting foreign policy approaches that demonstrate this dynamic and autonomous character as a small state has permitted such countries to be perceived as 'punching above their weight.' This has allowed for the crafting of compelling narratives that demonstrate authority within and beyond a regional context that challenges assumptions about power. As such, discourse about the necessary element of 
dependence in the literature on small states, can, we argue, be appreciated in these contexts as a much more malleable and dynamic phenomenon that hitherto conceived (Henrikson 2001).

Niche diplomacy does appear to promise much in terms of either middle powers or small states and their status in the international system. Discourse addresses effectiveness within foreign policy and emphasizes the 'creative use of diplomatic talents or entrepreneurship' (Cooper 1997, 9). For small states such as Kuwait or Qatar, the argument that a niche offers a unique launch pad for the construction of narratives and agency around it does appear compelling in seeking to understand how such states amplify their status on the global stage. Cooper seems to account for this by arguing that as such these small countries 'identify and fill niche space on a selective basis through policy ingenuity and execution' (Cooper 1997, 3). The logic of such an argument appears, however, to be limited in terms of recognizing particular realities around power dynamics, creativity, constraint, capacity and control in small non-liberal and non-democratic states. Nevertheless, authors such as Nye assert that Qatar, for example, exemplifies niche diplomacy and he describes the country as important to a sort of middle ground 'between the West and the Arab mainstream' (Nye 2008). Such assertions clearly unconsciously perpetuate unhelpful construction and problematic dichotomies between the so-called 'West' and the so-called Arab mainstream rather than carefully advance the discourse on niche diplomacy. As such, it, as Fromm contends, continues to advance niche theory from a 'neorealist tradition' and its attendant assumptions about the post-Cold War world and the international state system (Fromm 2019, 24).

Defining small state power within niche diplomacy settings also reflect attenuated meanings proffered by Kamrava (2013) as 'subtle power'. While helpful, such discourse allows for permissive post hoc construction to amplify power in contexts that are rarely transparent exemplars of insight into governance and decision-making. As such, they delimit and are not necessarily useful indicators of the true limits of the small state niche diplomacy universe. Henrikson echoes Kamrava in reifying the niche actor in the diplomatic sphere 'by virtue of its favoured situation, special competence or unique product ... considered as being locational, traditional or consensual-or some combination thereof' $(2005,71)$. In the example of Kuwait, we do see attendance to the construction of a slightly compelling niche around the country's late ruler Sheikh Sabah al-Ahmad al-Sabah as a 'Dean of diplomacy and mediation' that was unique to this leader in the Gulf region. Intimations of what lays ahead for such states are perhaps discernible in looking at the value of this discourse in relation to the outbreak of the COVID-19 global pandemic in 2020.

\section{COVID-19 and pandemic politics}

By spring 2020, it was already obvious that COVID-19 and its global effects constituted a crisis. This demanded new political approaches and ways of seeing international relations. While analysts differed over some issues, such as the actual endurance of the virus, there was an emerging consensus that international relationships would alter (Allen et al. 2020). This has had obvious implications for small states. 
For countries like Kuwait and Qatar, there have been a number of endogenous as well as exogenous implications. In the exogenous realms, these countries are members of an international state system relying on diplomatic, economic, security and other relations where theoretically their status as small states works against their interests and might have disadvantaged them with respect to vaccine procurement, food security, research and development, and international coalition building. Their unique national profiles and small state designation (including how their main sources of state revenue are accrued and how their security in a highly unstable geostrategic context is achieved) means that such states are frequently dependent on a number of primary bilateral relationships with larger and more powerful countries that have been hugely affected by the COVID-19 pandemic. Both countries, for example, rely on export of hydrocarbons (oil or LNG) to Asian states such as China, the Republic of Korea and Japan, as a primary source of state earnings. Moreover, both countries are also caught on the horns of dependent relationships between the two competing and increasingly rivalrous global powers of China and the USA and the exacerbation of tension between them throughout the COVID-19 pandemic. We would argue that an interface of exogenous and endogenous impacts is also reflected in the issue of migrant workers in these contexts (Barbar 2021).

Hence, the prospect of a changed world order more (or less) dominated by China, where the USA struggles to regain dominance through the Biden administration approach of alliance building and consensus seeking, where the forces of globalization retract and international cooperation decreases; where national security concerns broaden to include health, climate change and food security, where free trade and the price and demand for hydro-carbon energy plummets all matter immensely to the two small states. Even if the international system does not change entirely, the COVID-19 pandemic and related impacts on economies, social order and diplomatic relations have already disrupted a economic trade and growth patterns and exacerbated a number of political trends that not only strongly impact Kuwait and Qatar but demand that ways of projecting smallness, maintaining resilience and autonomy impact foreign policy and the narrative scaffold that supports them. There is already evidence in both countries that some foreign policy formulas have been maintained but the degree to which they continue to secure power and project influence becomes increasingly questionable.

We call this phase pandemic politics and it is already evident that it has been framed within overarching narratives associated with small states and niche diplomacy concepts. Such diplomacy is now operationalized in an international system that is increasingly typified by nation-states that are inward-looking, protectionist, nationalistic and economically cautious. It also reflects the ongoing decline of American leadership in the world and, weakening of the multilateral system with its attendant norms and values (Tooze 2020). Impacts of COVID-19 are already further undermining fragile states, aggravating social and political tensions, have given authoritarian leaders a green light to further repress legitimate grievances and weaken international energies directed as crisis management as well as diplomacy and peace negotiations. This is bad news for small outwardly facing states like Kuwait and Qatar whose diplomatic reputation and soft power credentials are tied 
to niche realms such as preventive conflict, strategic humanitarianism and branding associated with mediation, sport, culture, tourism and aviation.

It is already evident that states have not tended to work cooperatively during the pandemic. Even extant regional cooperation and international organizationslike the EU/GCC/Arab League/AU/WHO/UN_have been powered-down leading to further questions about their utility in the future. Some analysts refer to this as lamentable, unprecedented and a sign that globalization is in almost fatal decline (Wright 2020). These issues affect the ways in which countries like Kuwait and Qatar address their foreign policy agenda and crisis management approach.

It means that available resources, capacities and capabilities are required to be deployed through ongoing practice norms such as soft power labels of humanitarianism and brands such as the Kuwait Fund, Qatar Fund for Development (QFFD) and Qatar Airways. This is not to say that the two countries are the same, for indeed, there are differentials apparent in the soft power approaches they each take. Nevertheless, such states hope to create opportunities for more influence among and in international diplomatic forums such as the U.N. as well as continue to enhance their status as regional hubs. It also begins to signal how such states perceive changing balances of power wrought by pandemic politics in the international order reinforcing many norms traditionally associated in the scholarly literature on small states and niche diplomacy.

\section{Mask diplomacy as niche diplomacy?}

We see evidence from both Kuwait and Qatar of a concerted effort to augment extant narratives and projections of power internationally throughout the pandemic. This is characterized by the obvious conversion of dimensions of pre-existing humanitarian diplomacy narratives and gestures into what we call mask diplomacy. Mask diplomacy is defined by COVID-19 specific aid and assistance initiatives organized by both states through their rulers, and government, including foreign policy, foreign aid and assistance initiatives.

It is literal and symbolic attending to and, by varying degrees, further cultivating the project of an image by both Kuwait and Qatar of their outsized global status as small countries. It is a construct that has established narratives of the indispensability in the regional and thus international effort that has been required to respond with alacrity to the pandemic, its spread and efforts to vaccinate. When other states, small and large, appear to have floundered in both their national and international responses to the crisis or appeared to prioritize other issues Kuwait and Qatar rode the crest of a humanitarian wave signified through narratives of global cooperation and good citizenship.

It has been epitomized by Kuwait's major donation of $\$ 60$ million in early April 2020 to the World Health Organization (WHO) Covid-19 Strategic Preparedness and Response plan making it one of the largest donors at that point in the pandemic (WHO 2020). Both countries quickly mobilized to make well-publicized donations of basic medical supplies such as face masks and hand sanitizer to China. Kuwait's leaders announced a decision to give $\$ 3$ million worth of medical supplies to be sent 
to Wuhan while Doha announced the donation of supplies as well as free air freight of aid to China on the national carrier Qatar Airways. This was then followed with the provision of humanitarian assistance by both countries (and the UAE) to neighbouring Iran where the pandemic threatened to overwhelm (Rosen 2020).

Interestingly, despite differences in national crisis management, including vaccine protocols, responses to the pandemic in their own countries Kuwait and Qatar have actually displayed similar approaches to exogenous messaging, mask diplomacy and foreign policy priority setting. These focus on niche narratives as humanitarian actors that promote solidarity and unity in times of crisis. They tend, however, to play down or have a largely reactive function when it comes to foreign policy issues relating in particular to migrant workers.

Unlike Kuwait Qatar's contributions had initially been devoid of what we term "showcase" pledges to multilateral global public health organizations like WHO or GAVI which have then been utilized in the promotion of broader diplomatic messaging. This appeared to buck the post-2017 trend exhibited by Qatar where a greater and greater proportion of their humanitarian aid allocations were pledged and assigned to multilateral organizations including various UN organizations. Moreover, Qatar has assiduously utilized dimensions of its pre-existing brand power, specifically Qatar Airways, to boost its humanitarian credentials during the pandemic (Brannigan and Giulianotti 2018). Qatar Airways has supported UNICEF logistical activities, announced a new two-year partnership with UNHCR and in partnership with the Embassy of France has created an aviation bridge for donations to China. Qatar Airways claims that as part of the COVID-19 humanitarian response effort that it has facilitated flights for over one million people to travel across the world back to their home countries and played its part in transporting over a 100,000 tonnes of medical equipment and aid relief during the pandemic. Such branding, one can argue, inevitably led to targeting by Anti-Qatar elements as part of their own disinformation campaigns (Jones 2020).

Given the importance of monarchic rule and bargain setting in both these countries, it was natural that head of state and personal leadership has been employed by both countries in publicizing the aid and assistance effort. Kuwait's ruling family have similarly maintained a high media profile in relation to mobilization of aid and assistance initiatives such as \$10 million to Iran to assist it. The Instagram page of the "KuwaitRulingFamily" highlights a catalogue of initiatives featuring the ruler and other family members throughout the crisis. In this respect, mask diplomacy has been firmly embodied by the al-Sabah family. Emir Sheikh Sabah Al-Ahmed Al-Jaber Al-Sabah, Kuwaiti Foreign Minister Sheikh Sabah Khaled Al-Hamad Al-Sabah, Emiri Diwan affairs minister Sheikh Ali Jarrah Al-Sabah, was made on behalf of the wider Al-Sabah family, Health Minister Sheikh Dr. Basel Al-Sabah and plays a part in shoring up (if handled correctly) their resilience in the face of an active semi-democratic domestic context. Moreover, while the ruling family contends with an active and, oft, confrontational parliamentary institution in a domestic context, the foreign policy file of the government is one where the al-Sabah family can exhibit a greater degree of shaping and influencing (Yom 2020).

Qatar's Amir is reported as having issued a number of personal directives to Doha's contributed aid and assistance to other countries during the pandemic. For 
example, in early March 2020, Qatar publicized the directive from its ruler to donate 29 tonnes of medical aid to Iran as rates of infection grew there. The ruler was again seen as instrumental in a directed $\$ 150$ million of financial support over 6 months to Palestinians in the Gaza Strip, helping them combat the spread of coronavirus. Similarly the Amir's own 'air force' was deployed, in cooperation with Italian defence forces, to dispatch aid to Italy and build two field hospitals together there. In early June 2020, Qatari assistance was finally showcased when the Amir pledged \$20 million to the global alliance for vaccines GAVI and again later in the month when Foreign Minister Mohammed Bin Abdelrahman al-Thani announced a pledge of $\$ 10$ million to WHO's activities to combat COVID-19 (Gulf Times 2020). In Qatar's case, like Kuwait, the role of the Amir has also been augmented by the roles played by leading members of the al-Thani family, in particular women, including Qatar Foundation head Sheikh Mozah - the mother of the ruling Amir-to demonstrate global leadership qualities and agency. Sheikha Mozah has been particularly prominent in global responses and calls for cooperation through UN institutions such as the UNESCO, the UN initiative of women leaders calling for collaboration to combat COVID-19, and the UN General Assembly. Qatar's Permanent Representative to the United Nations Sheikha Alya Ahmed bin Saif Al Thani has also played a high profile role throughout debates at the U.N. related to the pandemic, its effects on security, victims of terrorism, and vulnerable populations such as refugees and women.

Both Kuwait and Qatar claim to have a good record of responding to humanitarian emergencies. They also have promoted narratives about the ways in which both countries have shaped and devoted resources to long-term developmental issues, particularly in the Arab and Muslim world, among vulnerable refugee and displaced populations, women and children. In this respect, both have used strong track records of partnership with major UN and other Arab Development Group alliances to leverage their COVID-19 response plans. When it was first founded, the Kuwait Fund for Arab Economic Development (KF/AED) was considered somewhat a development institutional trailblazer (ElKahlout 2020). Nevertheless, the assiduousness with which Kuwait's foreign policy agenda was maximized through trend-lines of Kuwait's aid and assistance practice has been framed in part of a wider discourse about "dinar diplomacy" and influence (Assiri 1991). Elkhalout argues that "Kuwait is a generous though unpredictable donor that supports multilateral aid and, similar to many other state donors, is driven by a mixture of cultural, political, strategic and humanitarian considerations" $(2020,157)$.

During the COVID-19 pandemic, such characteristics are apparent. It is noticeable that the first instances of assistance publicized by KF/AED were actually directed internally to assist Kuwait's national response planning and resource demands to the unfolding pandemic. On March 24, 2020, the fund announced a release of 30 million Kuwaiti Dinars for domestic needs. Subsequent activity by the KF/AED on COVID19 response planning in relation to the needs of least developed and developed countries has been singularly tied within the coordinating platform hosted by the OPEC International Fund for Development (OFID) of the Arab Coordination Group (ACG). In late May 2020, a pledge of $\$ 10$ billion was jointly made by the member groups, including the Kuwait Fund and Qatar's Fund for Development (QFFD) and 
OFID to allocate to COVID-19 responses (OFID 2020). While Kuwait's development aid focus was initially domestic, Qatar's Fund for Development contributed COVID-19 aid into programmatic areas where it traditionally operated. Hence, early programmatic responses from QFFD saw donations of funding for health centres, mobile clinics, and into national health funds, such as in Jordan, for refugees and internally displaced peoples (MENAFN 2020).

Overseas development activities reflective of programmatic responses in both countries initially demonstrate scant evidence of strategic adjustments to account for the immediate as well as longer-term impacts of the COVID-19 pandemic. In some respects, this is not unusual. Kuwait and Qatar, like other countries across the globe, have tended instead, to rely on limited emergency statements and gestures. Qatar's initial responses during the pandemic, for example, inclined to be reactive and did not always reflect past patterns of small state leveraging through alliance building and support. It also attempted to build on a narrative of 'preparedness' and a 'reputation for resilience built up during 3 years of blockade imposed on the country by the Arab quartet'. Claims centred on the ongoing abilities of decision-makers in Qatar to quickly organize logistical, humanitarian and medical assistance in times of crisis. Here was a narrative that could leverage Qatar's humanitarian diplomacy branding with its key trademark national carrier, Qatar Airways, and development institutions and fund givers the QFFD and Qatar Charity.

Humanitarian aid and assistance by Gulf countries have always been seen as a "quiet tool" and diplomatic resource for the many smaller states such as Kuwait to power-up and gain visibility in a variety of arenas (Young 2015). Moreover, dimensions of such aid have, according to some arguments, become weaponized in the wake of the blockade on Qatar in 2017. Barakat, et al., for example, argue that the blockade of Qatar and subsequent Gulf rift "has further politicized Gulf humanitarian action. The blockading states labelled Qatar a 'terror financier', singling out its humanitarian aid as one arm of a controversial foreign policy that supports Islamist movements across the Arab world $(2019,67)$. Saudi Arabia and the UAE, however, have also been accused of politicizing humanitarian aid, particularly with respect to Yemen where, since 2015, the Saudi-led military coalition has engaged (Salisbury 2018). The COVID-19 crisis and the strategic decision-making process implicit in the offers of aid and assistance from Gulf countries, that is, it is argued nothing more than a new facet of politicized aid (Soubrier 2020). While some have been optimistic that the pandemic and offers of humanitarian aid by Gulf countries create new routes to better relations within the region, most have tended to see it as nothing more than an opportunity to amplify division rather than promote meaningful and sustainable cooperation.

\section{Small states beyond COVID-19}

It is too soon to definitively assess direct and substantial impacts caused by COVID19 to the soft power diplomacy of Qatar and Kuwait. Nevertheless incipient evidence, such as the effort by GCC to maintain cooperation over public health while a Blockade had been maintained against Qatar, point to at least short-term impacts. 
By the summer of 2021, both Kuwait and Qatar's governments had begun the task of easing their countries from lockdowns into recovery mode. Forms of hydrocarbon export and security dependencies, however, have not allowed these countries the luxury of diplomatic self-shielding or quarantine. In order to survive and, in Qatar's case, prepare to showcase their country globally in 2022 when they host the FIFA World Cup, foreign policy strategies have had to be maintained.

A cornerstone of Kuwait and Qatar's foreign policy is national security. Pandemic politics, however, requires such small states reassess their national interests and to broaden their conception of national security. While many disagree about the extent to which we are going to be living in a post-American global order, there is a consensus that the COVID-19 pandemic highlights or even accelerates changes in the way in which the USA acts as a global power. Furthermore, the extent to which the domestic response to COVID-19 in America or China accelerates or holds back the recovery process is of key concern to hydro-carbon producing countries like Kuwait and Qatar.

Kuwait and Qatar have strong bilateral relationships with the USA particularly, as small countries, in relation to security sheltering. As such, both countries have tended to ignore the fact that under President Trump his government's policies have undermined the sovereignty and power of small states in the Gulf (Bordoff 2020). We would contend that because of the limits of strategic manoeuvre that Kuwait and Qatar have as small states they have to suffer slings and arrows thrown at them resulting from US preference for dealing with bigger states in the region, particularly when negotiating new regional security arrangements. Throughout the COVID-19 pandemic, small states like Kuwait have been virtually bereft and frequently reminded of the fact that US leadership is absent or unreliable. In the current pandemic, analysts pointed to a marked lack of US leadership on the world stage under Trump and a hope for reassertion under Biden. As the US continues its retreat from the Middle East, we know that other states, including China, Russia and middle powers in the Gulf such as Iran, and Saudi Arabia, will seek to take advantage. Small states have to begin to take account of this change when they make their own security calculations and in also balancing other primary bilateral relationships post-COVID-19.

Decision-makers in small states like Kuwait have to consider whether it is enough to continue to ignore the US retreat, its transactional preference for states like Saudi Arabia in alliance formation, its risky policies of confrontation with Iran in the Gulf and absence from its traditional role in addressing major transnational issues, so long as the cost-benefit analysis allows for a continuing security guarantee. Such decision-makers also have to include the risk and vulnerabilities that a post-pandemic event horizon creates in terms of US decision-making, the decline of the socalled American model.

This is evident in a variety of ways. Soft power credentials now need to expand and evolve conceptually to include global public health policy, digital nations and economies, the nexus between technological development and international cooperation and the particular strains on small city-states such as Kuwait and Qatar. With healthcare featuring much more prominently in international system policyplanning it can also be contended that $R \& D$ is key, especially in relation to medical 
equipment as well as pharmaceutical patents and production. Even though in the wake of the Blockade on Qatar, local experts highlighted their vulnerabilities in terms of a weak R\&D contexts as well as obstacles to manufacturing pharmaceuticals and medically equipment locally the pandemic reveals the extent to which such approaches remained absent from foreign policy priority setting and the nexus to national security.

As such, both Kuwait and Qatar continued to rely on imports for medical supplies, equipment and expertise throughout the pandemic with implications for their foreign policy assessments with major pharma and medical equipment producing countries post-pandemic. The same is true with respect to digital and technology realms, with both countries becoming reliant on remote working digital and technology-based communication and employment. Such dependencies mean that Kuwait and Qatar must be ever-vigilant and double-down on cyber-security threats and protection which in turn necessarily entail relationship building with states such as China. There is already evidence of malign threats in exploitation of the pandemic to target Qatar (Ulrichsen 2020b). Malware attacks, and sponsored campaigns to exploit the situation through VPN, videoconferencing and software lures have all been deployed to take advantage of the situation and attack. At the level of foreign policy, this means that an assessment of cyber-security cooperation protocols, agreements and mechanisms with other countries as well as choices about preferred providers of next generation (incl. 5G) technologies becomes all the more important. These, however, are under-powered realms in terms of framing narratives and policy approaches and are thus largely absent from the ways in which states like Kuwait promote themselves. It is thus a diplomatic niche that others have filled including small Asian states such as the Republic of South Korea (Won Sonn and Lee 2020).

As small states, we have already demonstrated the ways in which Kuwait and Qatar place a premium on its network of international relationships. In the wake of COVID-19, it will be necessary to reassess their analysis of threats and opportunities bilaterally as well as multilaterally. Some elements of interaction with the globe may need to be realigned.

\section{Conclusion: small states and the limits of niche diplomacy}

As outlined above, in the past, both Kuwait and Qatar consistently attempted to leverage their status and build resilience in dimensions of their sovereignty by establishing external facing narratives as small states that could punch above their weight in diplomatic niches such as humanitarianism and conflict resolution. Furthermore, both countries have tended to rely on mechanisms of sheltering with larger state powers as well as opportunities to promote multilateralism as a cornerstone of foreign policy approaches. This has both altruistic and instrumental strategic value.

Nevertheless, it became rapidly apparent from emerging analyses that mechanisms, institutions and elites formerly embodying international cooperation and global leadership have had a much reduced profile during the Coronavirus pandemic. This has significant implications in terms of diplomacy, international political economy as well as global public healthcare and medical cooperation. Some 
have gone as far as to argue that the longer the crisis endures the higher the risk of an 'evisceration' of international cooperation (Wright 2020).

Global governance and associated norms have thus been effectively weakened undermining the abilities of small states to power-up through multilateral institutions and to project authority beyond their size. The overwhelming nature of the global pandemic has also required states within the international system to endure what has become an unprecedented cycle of contagion, lockdown, ease, contagion and lockdown. Foreign policy has moved into a realm of emergency management and reaction. In the Gulf, Kuwait and Qatar were already located in a strategic environment where inter-state cooperation, and the institutions that were supposed to embody those norms were failing and, in the case of Qatar, undermining sovereignty.

The efforts and resources pledged and distributed by Kuwait and Qatar during the initial phase of the pandemic breaking out, first in China, then the Middle East and beyond can, in part, be considered constitutive of mask diplomacy. This is because it signifies that ways in which these countries have used resources to power-up through the pandemic, especially in relation to showcase contributions to WHO, GAVI and other global initiatives to tackle the public health crisis as well as the search for a vaccine for everyone. This permits both Kuwait and Qatar to make claims around the ethical and moral good. The limits of mask diplomacy, however, are also exposed.

\section{References}

Allen, J., N. Burns, L. Garrett, R.N. Haass, G.J. Ikenberry, K. Mahbubani, S. Menon, R. Niblett, J.S. Nye Jr., S.K. O’Neil, and K. Schake. 2020. How the World Will Look After the Coronavirus Pandemic. Foreign Policy 20: 2020.

Antola, E. 2002. The future of small states in the EU. In European integration in the 21st century, ed. M. Farrell, S. Fella, and M. Newman, 69-86. London: Sage.

Assiri, Abdul-Reda. 1991. Kuwait's Dinar Diplomacy: The Role of Donor-Mediator. Journal of South Asian and Middle Eastern Studies 14 (3): 24-32.

Bailes, A.J.K., B.A. Thayer, and B. Thorhallsson. 2016. Alliance Theory and Alliance 'Shelter': The Complexities of Small State Alliance Behaviour. Third World Thematics: A Third World Quarterly 1 (August): 9-26.

Barakat, S. (2019) Priorities and challenges of Qatar's Humanitarian Diplomacy. CMI Brief, (07).

Barakat, S., \& Zyck, S. A. (2010) Gulf state assistance to conflict-affected environments. Kuwait Programme on Development, Governance and Globalisation in the Gulf States (10). London School of Economics and Political Science, London, UK.

Barbar, Z.R. (2021). Pandemic Mobilities in the Persian Gulf: Unpacking the "Crises". https://www. arnold-bergstraesser.de/sites/default/files/field/pub-download/qatar_babar.pdf, accessed 7 July 2021.

Bordoff, J. (2020) Oil crash winner, Saudi Arabia, Foreign Policy, 20, https://foreignpolicy.com/2020/05/ 05/2020-oil-crash-winner-saudi-arabia/, accessed 7 July 2020.

Brannagan, P.M., and R. Giulianotti. 2018. The soft power-soft disempowerment nexus: The case of Qatar. International Affairs 94 (5): 1139-1157.

Elkahlout, G. 2020. 'Hearts and Minds': Examining the Kuwaiti Humanitarian Model as an Emerging Arab Donor. Asian Journal of Middle Eastern and Islamic Studies 14 (1): 141-157.

Fox, A.B. 1959. The power of small states. Chicago: Chicago University Press.

Freer, C., (2015) Rentier Islamism: Muslim Brotherhood affiliates in Kuwait, Qatar, and the United Arab Emirates. https://ora.ox.ac.uk/objects/uuid:134ca923-a204-40bf-80be-4e21352e680b accessed 27 June 2020.

Fromm, N. 2017. Constructivist niche diplomacy: Qatar's Middle East diplomacy as an illustration of small state norm crafting. Hamburg: Springer. 
Gulf Times. 2020. Qatar pledges $\$ 10 \mathrm{mn}$ for WHO's fight against Covid. https://www.gulf-times.com/ story/666716/Qatar-pledges-10mn-for-WHO-s-fight-against-Covid accessed 22 July 2020.

Handel, M. 1981. Weak States in the International System. Totowa, NJ: Frank Cass.

Henrikson, A.K. 2001. A coming 'Magnesian' age? Small States, the Global System, and the International Community, Geopolitics 6 (3): 49-86.

Henrikson, Alan K. 2005. Niche Diplomacy in the World Public Arena: The Global 'Corners' of Canada and Norway. In The New Public Diplomacy: Soft Power in International Relations, ed. Jan Melissen, 67-87. New York: Palgrave Macmillan.

Hey, J.A.K. 2003. Small states in world politics: Explaining foreign policy behavior. London: Lynne Rienner.

Jesse, N.G., and R.J. Dreyer. 2016. Small States in the International System: At Peace and at War. Lanham, MD: Lexington Books.

Jones, M.O. 2020. Disinformation superspreaders: The weaponisation of COVID-19 fake news in the Persian Gulf and beyond. Global Discourse: An Interdisciplinary Journal of Current Affairs 10 (4): 431-437.

Khatib, Lina. 2013. Qatar's foreign policy: The limits of pragmatism. International Affairs 89 (2): 417-431.

Leichtman, M.A., 2017. Kuwaiti Humanitarianism: The History and Expansion of Kuwait's Foreign Assistance Policies. Stimson Center..

McKinnon, M. 1997. Friends in Need: The Kuwait Fund in the Development World. London: I.B. Tauris.

MENAFN (2020), Int'l donors contribute $187 \mathrm{~m}$ to support Jordan's CVOID-19 efforts, May 21, https:// menafn.com/1100203448/Intl-donors-contribute-187m-to-support-Jordans-COVID-19-efforts, accessed 13 July 2020.

Nye, Joseph S. 2004. Soft Power: The means to success in world politics. Cambridge: Public Affairs.

Nye, Joseph S. (2008) Qatar is a diplomatic heavy-hitter, al-Jazeera, 21 May, https://www.aljazeera.com/ focus/2008/07/200872164735567644.html accessed 27 June 2020.

OFID (2020), Communique, https://opecfund.org/news-stories/us-10-billion-joint-covid-19-response-fordeveloping-countries, accessed 9 July 2020.

Peterson, J. E. (2006). Qatar and the world: Branding for a micro-state. The Middle East Journal, October (1): 732-748.

Rosen, L. (2020) Coronavirus spur humanitarian outreach to Iran, Al Monitor, https://www.al-monitor. com/pulse/originals/2020/03/coronavirus-spur-humanitarian-outreach-iran.html, accessed 13 July 2020.

Salisbury, P. (2018) Aiding and Abetting? The GCC states, foreign assistance and shifting approaches to stability, Baker Institute, Center for Middle East, https://www.bakerinstitute.org/media/files/files/ 8cb451f5/cme-pub-carnegie-salisbury-091718.pdf, accessed 14 July 2020.

Soubrier, E. (2020) Gulf humanitarian diplomacy in a time of Coronavirus, AGSIW, https://agsiw.org/ gulf-humanitarian-diplomacy-in-the-time-of-coronavirus/, accessed 13 July 2020.

Steinmetz, R., and A. Wivel. 2016. Small States in Europe: Challenges and Opportunities. New York: Routledge.

Tooze, A. (2019) Everything you know about the global order is wrong, Foreign Policy, 30 January, https://foreignpolicy.com/2019/01/30/everything-you-know-about-global-order-is-wrong/, accessed 5 June 2020.

Ulrichsen, K.C. (2013) From Mediation to Interventionism: Understanding Qatar's Arab Spring Policies, Global Affairs. http://eng.globalaffairs.ru/number/ From-Mediation-to-Interventionism-16170, accessed: 7 July 2020.

Ulrichsen, K.C. 2020a. Qatar and the Gulf Crisis: A Study of Resilience. USA: Oxford University Press.

Ulrichsen, K.C. 2020b. The coup that never was: How a disinformation campaign created the illusion of political chaos in Qatar, Responsible Statecraft, May 7. https://responsiblestatecraft.org/2020/05/ 07/the-coup-that-never-was-how-a-disinformation-campaign-chaos-in-qatar/, accessed July 7, 2020.

Vital, D. 1971. The Survival of Small States: Studies in Small Power/Great Power Conflict. Oxford, UK: Oxford University Press.

Walt, S.M. 1987. The origins of alliance. Ithaka: Cornell University Press.

Waltz, K.N. 1986. Reductionist and systemic theories. In Neorealism and its critics, ed. R.O. Keohane, 47-69. New York: Columbia University Press.

Waltz, K.N. 1991. Realist thought and neorealist theory. In Theory in International Relations, ed. R.L. Rothstein. Columbia: University of South Carolina Press. 
Wintour, P. (2017) Gulf plunged into diplomatic crisis as countries cut ties with Qatar, The Guardian, 5 June, https://www.palgrave.com/gp/journal/41311/authors/presentation-formatting, accessed 5 June 2020.

Wohlforth, W.C., B. De Carvalho, H. Leira, and I.B. Neumann. 2018. Moral authority and status in International Relations: Good states and the social dimension of status seeking. Review of International Studies 44 (3): 526-546.

Won Sonn, J., \& Lee, J. K. (2020). The smart city as time-space cartographer in COVID-19 control: the South Korean strategy and democratic control of surveillance technology. Eurasian Geography and Economics, 1-11.

World Health Organization (2020), Covid19 virtual press conference, April 3, https://www.who.int/docs/ default-source/documents/covid-19-virtual-press-conference-transcript-3-april-2020.pdf?sfvrsn= 43e2f2f3_6, accessed 6 July 2020.

Wright, T. (2020) Stretching the international order to its breaking point, Order from Chaos, Brookings, 6 April https://www.brookings.edu/blog/order-from-chaos/2020/04/06/stretching-the-internationalorder-to-its-breaking-point/, accessed 8 April 2020.

Yom, S. 2020. Roles, identity, and security: Foreign policy contestation in monarchical Kuwait. European Journal of International Relations 26 (2): 569-593.

Young, K. E. (2015). The limits of Gulf Arab aid: energy markets and foreign policy. Reflections' Working Paper Series, 1, 43-53.

Publisher's Note Springer Nature remains neutral with regard to jurisdictional claims in published maps and institutional affiliations. 